\title{
Anesthesia of Epinephelus marginatus with essential oil of Aloysia polystachya: an approach on blood parameters
}

\author{
CARINE O. FOGLIARINI ${ }^{1}$, QUELEN I. GARLET ${ }^{2}$, THAYLISE V. PARODI ${ }^{3}$, \\ ALEXSSANDRO G. BECKER ${ }^{4}$, LUCIANO O. GARCIA ${ }^{5}$, BERTA M. HEINZMANN ${ }^{2}$, \\ ANA MARIA S. PEREIRA ${ }^{6}$ and BERNARDO BALDISSEROTTO ${ }^{1}$ \\ ${ }^{1}$ Departamento de Fisiologia e Farmacologia, Universidade Federal de Santa \\ Maria, Av. Roraima, 1000, 97105-900 Santa Maria, RS, Brazil \\ ${ }^{2}$ Departamento de Farmácia Industrial, Universidade Federal de Santa Maria, \\ Av. Roraima, 1000, 97105-900 Santa Maria, RS, Brazil \\ ${ }^{3}$ Universidade Regional Integrada do Alto Uruguai e das Missões, Prédio 9, Av. \\ Batista Bonoto Sobrinho, 733, 97700-000 Santiago, RS, Brazil \\ ${ }^{4}$ Centro de Ciências do Mar/ CCMAR, CIMAR - Laboratório Associado, Universidade \\ do Algarve, Campus de Gambelas, 8005-139 Faro, Portugal \\ ${ }^{5}$ Instituto de Oceanografia, Estação Marinha de Aquicultura, Universidade Federal do Rio \\ Grande/ FURG, Caixa postal 474, 962010-030 Rio Grande, RS, Brazil \\ ${ }^{6}$ Universidade de Ribeirão Preto, Av. Constabile Romano, 2201, 14100-000 Ribeirão Preto, SP, Brazil
}

Manuscript received on July 21, 2016; accepted for publication on September 1, 2016

\begin{abstract}
This study investigated the anesthetic potential of the essential oil (EO) of Aloysia polystachya in juveniles of dusky grouper (Epinephelus marginatus). Fish were exposed to different concentrations of EO of $A$. polystachya to evaluate time of induction and recovery from anesthesia. In the second experiment, fish were divided into four groups: control, ethanol and 50 or $300 \mu \mathrm{L} \mathrm{L}^{-1} \mathrm{EO}$ of A. polystachya, and each group was submitted to induction for $3.5 \mathrm{~min}$ and recovery for 5 or $10 \mathrm{~min}$. The blood gases and glucose levels showed alterations as a function of the recovery times, but $\mathrm{Na}^{+}$and $\mathrm{K}^{+}$levels did not show any alteration. In conclusion, the $\mathrm{EO}$ from leaves of $A$. polystachya is an effective anesthetic for dusky grouper, because anesthesia was reached within the recommended time at EO concentrations of 300 and $400 \mu \mathrm{L} \mathrm{L}^{-1}$. However, most evaluated blood parameters showed compensatory responses due to EO exposure.
\end{abstract}

Key words: anesthetic efficacy, blood gases, glucose, hemoglobin, plasma ion levels.

\section{INTRODUCTION}

Several procedures of fish culture such as handling, blood sampling, transporting and vaccination often

Correspondence to: Bernardo Baldisserotto

E-mail: bbaldisserotto@hotmail.com

* Contribution to the centenary of the Brazilian Academy of Sciences. generate a stress response in the animals (Kiessling et al. 2009, Zahl et al. 2012). Firstly, activation of the hypothalamic-pituitary-interrenal axis occurs, with subsequent release of catecholamines and cortisol. As a consequence, glucose and lactate increase and osmoregulatory disturbances occur (Zahl et al. 2012). Anesthetics obtained from 
plants, such as the essential oil (EO) of Lippia alba (Cunha et al. 2010, Azambuja et al. 2011, Becker et al. 2012, Heldwein et al. 2012, Salbego et al. 2014), Ocimum gratissimum (Silva et al. 2012), Hesperozygis ringens (Silva et al. 2013, Toni et al. 2014) and Aloysia triphylla (Gressler et al. 2014, Parodi et al. 2014, Zeppenfeld et al. 2014) showed efficacy and safety for use in aquaculture procedures.

The EO used in the present study was obtained from leaves of $A$. polystachya (Griseb.) Moldenke (Verbenaceae), an aromatic native plant widely distributed in subtropical regions of South America, mainly in Paraguay and North Argentina, and popularly known as "burrito", "poleo de Castilla" or "poleo riojano". This plant is referred to as a sedative (Del Vitto and Petenatti 1997) and is also used against gastrointestinal pain in folk medicine (Filipoy 1994). Studies with mice and rats indicated that the hydro-ethanolic extract from the aerial parts of $A$. polystachya has anxiolytic and antidepressant-like effects (Mora et al. 2005, Hellión-Ibarrola et al. 2006, 2008).

The dusky grouper, Epinephelus marginatus (Serranidae) has a wide distribution, occurring along the Mediterranean Sea and in the Indian Ocean to the southeast of the African continent (Fennessy 2006). On the west coast of the Atlantic Ocean, the dusky grouper occurs from Rio de Janeiro to the New Gulf region in Argentinean Patagonia (Figueiredo and Menezes 1980, Irigoyen et al. 2005). Since E. marginatus is a target species for aquaculture (Cunha et al. 2013, Cavalli 2014, Sanches et al. 2014), the present study investigated the anesthetic potential of the EO of $A$. polystachya in dusky grouper juveniles. Some blood parameters were also analyzed, aiming to evaluate possible side effects of this EO.

\section{MATERIALS AND METHODS}

PLANT MATERIAL AND ESSENTIAL OIL EXTRACTION

Aloysia polystachya (Griseb.) Moldenke (Verbenaceae) was cultivated in the medicinal plant garden of "Nature's Pharmacy", Municipality of Jardinópolis, SP, Brazil. The leaves were harvested in September 2012 at 10 am and dried in an oven with forced air circulation at a temperature of $45^{\circ} \mathrm{C}$ for $48 \mathrm{~h}$. The voucher specimen (UPMU No. 1213) was identified by Dr. Rossi from the Institute of Botany of São Paulo, and a voucher was deposited in the Herbarium of Medicinal Plants at the University of Ribeirão Preto, SP, Brazil. The EO was extracted from dried leaves by hydrodistillation using a Clevenger-type apparatus according to the European Pharmacopoeia (2007).

ESSENTIAL OIL ANALYSIS

The EO samples were analyzed by GC-MS with an Agilent 6890A gas chromatograph equipped with a 5973C mass selective detector using a nonpolar HP5-MS fused silica capillary column (5\% phenyl, 95\% methylsiloxane, $30 \mathrm{~m}$ x $0.25 \mathrm{~mm}$ i.d. $\mathrm{x} 0.25 \mu \mathrm{m}$ film thickness) and electron ionization mode at $70 \mathrm{eV}$. Helium was used as carrier gas at a flow rate of $1.0 \mathrm{~mL} \mathrm{m^{-1 }}$; the injector and detector temperatures were set at 250 and $280{ }^{\circ} \mathrm{C}$, respectively. Oven temperature was kept at $40{ }^{\circ} \mathrm{C}$ for $4 \mathrm{~min}$ and then gradually raised to $320{ }^{\circ} \mathrm{C}$ at 4 ${ }^{\circ} \mathrm{C} \mathrm{min}^{-1}$. Injections were performed in split inlet mode (ratio 1:100). Kovats retention indices were calculated using a homologous series of C7-C31 n-alkanes injected under the same conditions. The EO constituents were identified by comparison of the mass spectra and Kovats retention indices with literature data and with the National Institute of Standards and Technology (NIST) Mass Spectral 
Library (NIST 2008, Adams 2009). FID analysis was performed in an equivalent column and using the same oven parameters as described for GC-MS. Both injection and detection temperatures were set at $300{ }^{\circ} \mathrm{C}$ and the split inlet mode ratio was 1:50. The percentage of EO compounds was calculated by under peak area integration.

\section{ANIMALS AND WATER CONDITIONS}

Dusky grouper $(82.0 \pm 2.3 \mathrm{~g} ; 16.7 \pm 0.1 \mathrm{~cm})$ juveniles obtained from a fish culture in Rio Grande, southern, Brazil, were maintained for one week in $250 \mathrm{~L}$ continuously aerated tanks to acclimate to laboratory conditions. The animals were fed once a day with commercial feed and kept fasted for a period of $24 \mathrm{~h}$ prior to the experiments that were conducted in accordance with the Ethical Committee and the Animal Welfare Committee of UFSM (process number 074/2014). The water parameters were measured as follows: dissolved oxygen $\left(6.20 \pm 0.11 \mathrm{mg} \mathrm{L}^{-1}\right)$ and temperature $\left(26.29 \pm 0.12^{\circ} \mathrm{C}\right)$ with a YSI oxygen meter (model DO 200A), pH (7.2 \pm 0.1$)$ with a pH meter (Hanna Instruments, Woonsocket, RI, USA; model HI $8424)$, total ammonia nitrogen $(0.25 \pm 0.06 \mathrm{mg} \mathrm{N}$ $\mathrm{L}^{-1}$ ) measured by the salicylate method (UNESCO 1983), nitrite $\left(0.08 \pm 0.03 \mathrm{mg} \mathrm{L}^{-1}\right)$ determined as described by Bendschneider and Robinson (1952) and alkalinity $\left(149.75 \pm 0.67 \mathrm{mg} \mathrm{CaCO}_{3} \mathrm{~L}^{-1}\right)$ by the method of Baumgarten et al. (1996). In addition, salinity was maintained throughout the experiment at 29 ppt.

\section{EXPERIMENT 1: ANESTHESIA INDUCTION AND RECOVERY}

The water conditions for this experiment were similar to those reported for acclimation. Juveniles were transferred with a net to a $10 \mathrm{~L}$ aquarium with the EO from the leaves of A. polystachya at 50, 75, $100,200,300$ or $400 \mu \mathrm{LL}^{-1}$, firstly diluted in ethanol $(1: 10)$. Moreover, the possible anesthetic effect of ethanol was tested with the highest concentration used to dilute the EO. The EO concentrations were chosen based on the study of Parodi et al. (2014) with the EO of $A$. triphylla. To evaluate the time required for anesthesia induction, six $(n=6)$ juveniles were individually tested using aquaria at the respective concentration. Each animal was used only once and the anesthesia stages were determined according to Small (2003): Stage 1: sedation - decreased reactivity to external stimuli; Stage 2: partial loss of equilibrium and erratic swimming; Stage 3: total loss of equilibrium and cessation of locomotion. The maximum observation time was $30 \mathrm{~min}$. After the induction of anesthesia, juveniles were transferred to anesthetic-free aquaria to measure the recovery time. Animals were considered to have recovered when they demonstrated normal swimming and reaction to external stimuli.

EXPERIMENT 2: BLOOD ANALYSIS OF ANESTHETIZED AND RECOVERED FISH

Animals were divided into the following groups ( $\mathrm{n}=6$ per treatment and time of collection): control (without anesthetic), ethanol, 50 or 300 $\mu \mathrm{L} \mathrm{L}^{-1}$ A. polystachya leaf EO. The collection times for each group were: exposure (3.5 min) and recovery times (5 or $10 \mathrm{~min}$ ). Each fish was sampled only once. Recovery was performed in anesthetic-free aquaria. After exposure or recovery times, blood was collected from the caudal vein of each fish by heparinized $1 \mathrm{~mL}$ syringes and immediately analyzed using an i-STAT portable clinical analyzer with CG8+ cartridge (Abbott Laboratories, Chicago, IL, USA). The parameters measured were: sodium $\left(\mathrm{Na}^{+}\right)$, potassium $\left(\mathrm{K}^{+}\right)$, calcium $\left(\mathrm{Ca}^{2+}\right)$, bicarbonate $\left(\mathrm{HCO}_{3}^{-}\right), \mathrm{pH}$, gases $\left(\mathrm{PvO} \mathrm{O}_{2}, \mathrm{Pv} \mathrm{CO}_{2}\right)$, glucose, hemoglobin $(\mathrm{Hb})$ and hematocrit (Hct). The clinical analyzer temperature was corrected to the water temperature according to the manufacturer's specifications. The efficacy of i-STAT measurements has been proved for several 
fish species (Cooke et al. 2008, Kristensen et al. 2010, Paust et al. 2011).

\section{STATISTICAL ANALYSIS}

All data are expressed as mean \pm SEM. The homogeneity of variances between treatments was calculated with Levene's test. As the data exhibited homogeneous variances, comparisons between different groups and times were made using two-way ANOVA and Tukey's test. Analyses were performed using Statistica ver. 7.0 software (StatSoft, Tulsa, OK, USA) with the minimum significance level set at $\mathrm{P}<0.05$.

\section{RESULTS}

\section{CHEMICAL COMPOSITION}

A total of 19 compounds were identified in the EO obtained from the dried leaves of A. polystachya (Table I). The main constituents found in this EO were carvone (58.76\%) and $\alpha$-limonene (33.68\%).

\section{INDUCTION AND RECOVERY TIMES FROM} ANESTHESIA

As expected, by increasing EO concentration there was a proportional decrease in the time required for sedation and anesthesia induction, but not for recovery. Fish exposed up to $75 \mu \mathrm{L} \mathrm{L}^{-1} A$. polystachya EO reached sedation (Stage 1), but no evidence indicated a possible deep anesthesia (Stage 3 ) during the evaluation time (maximum $30 \mathrm{~min}$ ). Concentrations above $100 \mu \mathrm{L} \mathrm{L}^{-1}$ EO were able to induce sedation and anesthesia. Recovery time was significantly faster at 200 and $300 \mu \mathrm{L} \mathrm{L}^{-1}$ EO than at $100 \mu \mathrm{L} \mathrm{L}^{-1}$, and the highest concentration tested (400 $\mu \mathrm{L} \mathrm{L}^{-1} \mathrm{EO}$ ) presented the fastest recovery time (Table II). Mortality was not observed throughout the anesthesia induction procedure. Ethanol added to the water did not produce any anesthetic effect.

\section{BLOOD PARAMETERS}

Blood $\mathrm{pH}$ was not significantly affected by treatments. The $P v \mathrm{O}_{2}$ and $\mathrm{PvCO}$ values increased and decreased, respectively, in fish placed in the simulated recovery, as well as in those recovering from ethanol exposure for $5 \mathrm{~min}$ compared to those exposed to ethanol. Groupers exposed to both EO concentrations presented higher $\mathrm{PvO}_{2}$ values than control fish. The $\mathrm{PvO}_{2}$ values were also higher in fish exposed to $50 \mu \mathrm{L} \mathrm{L}^{-1}$ EO than in those exposed to ethanol. The $P v \mathrm{O}_{2}$ values of fish recovered from $50 \mu \mathrm{L} \mathrm{L}^{-1}$ EO exposure were significantly lower than in exposed fish, but in those recovered from $300 \mu \mathrm{L} \mathrm{L}^{-1}$ EO exposure, these values were higher than in exposed fish and in the recovered control and ethanol groups. Groupers exposed to $300 \mu \mathrm{L}$ $\mathrm{L}^{-1}$ showed significantly higher $P v \mathrm{CO}_{2}$ values than the control group. In addition, fish recovered for 5 min presented significantly higher $P v \mathrm{CO}_{2}$ values than the control and ethanol groups, but after 10 min recovery these values were significantly lower than in the ethanol group. The $\mathrm{HCO}_{3}^{-}$concentration decreased in all groups at both recovery times when compared to exposure, but was not affected by treatments (Table III).

The levels of glucose, hemoglobin and hematocrit were not significantly different between exposure times in the control group (Fig. 1). Glucose levels also did not differ between times in the ethanol group. The groups treated with 50 or $300 \mu \mathrm{L} \mathrm{L}^{-1}$ EO showed higher glucose levels after $10 \mathrm{~min}$ recovery compared to other times. Fish exposed to $50 \mu \mathrm{L} \mathrm{L}^{-1}$ EO had increased glucose levels after $10 \mathrm{~min}$ recovery compared to the control and ethanol groups, but those exposed to $300 \mu \mathrm{L} \mathrm{L}^{-1}$ EO had decreased levels after 5 min recovery compared to the ethanol group (Fig. 1a).

Hemoglobin and hematocrit levels in the ethanol and $50 \mu \mathrm{L} \mathrm{L}^{-1} \mathrm{EO}$ groups were lower after 5 min recovery compared to the other exposure times. Groupers exposed to $50 \mu \mathrm{L} \mathrm{L}^{-1}$ EO showed lower 
TABLE I

Chemical composition of the essential oil from dried leaves of Aloysia polystachya.

\begin{tabular}{ccccccc}
\hline Peak & RT & Compound & $\begin{array}{c}\text { RI } \\
\text { experimental }\end{array}$ & RI literature & Source & \% \\
$\mathbf{1}$ & 10.23 & $\alpha$-Pinene & 931 & 937 & $\mathrm{~N}$ & 0.75 \\
$\mathbf{2}$ & 11.94 & $\beta$-Pinene & 974 & 975 & $\mathrm{~N}$ & 0.45 \\
$\mathbf{3}$ & 12.65 & $\beta$-Myrcene & 991 & 990 & $\mathrm{~N}$ & 1.57 \\
$\mathbf{4}$ & 14.05 & $\alpha$-Limonene & 1027 & 1028 & $\mathrm{~N}$ & 33.68 \\
$\mathbf{5}$ & 14.52 & $\beta$-E-Ocimene & 1039 & 1038 & $\mathrm{~N}$ & 0.40 \\
$\mathbf{6}$ & 14.91 & $\beta$-Z-Ocimene & 1049 & 1051 & $\mathrm{~N}$ & 0.21 \\
$\mathbf{7}$ & 16.93 & $\beta$-Linalool & 1100 & 1098 & $\mathrm{~N}$ & 0.93 \\
$\mathbf{8}$ & 17.69 & E-p-Mentha-2,8- & 1121 & 1118 & $\mathrm{~N}$ & 0.19 \\
$\mathbf{9}$ & 18.16 & Limonene epoxide & 1134 & 1136 & $\mathrm{~N}$ & 0.27 \\
$\mathbf{1 0}$ & 20.28 & $\alpha$-Terpineol & 1191 & 1190 & $\mathrm{~N}$ & 0.40 \\
$\mathbf{1 1}$ & 20.43 & 1,6 -Dihydrocarveol & 1195 & 1195 & $\mathrm{~N}$ & 0.29 \\
$\mathbf{1 2}$ & 20.50 & Dihydrocarvone & 1197 & 1199 & $\mathrm{~N}$ & 0.29 \\
$\mathbf{1 3}$ & 21.70 & E-Carveol & 1231 & 1233 & $\mathrm{~N}$ & 0.24 \\
$\mathbf{1 4}$ & 22.16 & Carvone & 1244 & 1242 & $\mathrm{~N}$ & 58.76 \\
$\mathbf{1 5}$ & 23.22 & Perillal & 1275 & 1274 & $\mathrm{~N} / \mathrm{A}$ & 0.17 \\
$\mathbf{1 6}$ & 23.86 & Thymol & 1293 & 1292 & $\mathrm{~N}$ & 0.16 \\
$\mathbf{1 7}$ & 27.99 & $\beta$-Caryophyllene & 1420 & 1419 & $\mathrm{~N}$ & 0.80 \\
$\mathbf{1 8}$ & 29.05 & $\alpha$-Caryophyllene & 1454 & 1455 & $\mathrm{~N}$ & 0.15 \\
$\mathbf{1 9}$ & 30.74 & $\beta$-Bisabolene & 1509 & 1509 & $\mathrm{~N}$ & 0.29 \\
\hline & \multicolumn{7}{c}{ Total identified: } & & & 100.00 \\
\hline $\mathbf{R T}$ & & & & \\
\end{tabular}

$\overline{\mathrm{RT}}=$ retention time (in $\mathrm{min}) ; \mathrm{RI}$ experimental = calculated Kovats retention index; RI literature = reference Kovats retention index; $\mathrm{N}=$ NIST Mass Spectral Library (2008) and A = Adams (2009).

hemoglobin and hematocrit levels than the ethanol group and lower hematocrit than the control group. After 10 min recovery, fish that were exposed to $300 \mu \mathrm{L} \mathrm{L}^{-1}$ EO presented lower hematocrit and hemoglobin levels than exposed fish. Fish exposed to $300 \mu \mathrm{L} \mathrm{L}^{-1}$ EO showed higher hemoglobin and hematocrit levels after $5 \mathrm{~min}$ recovery compared to the fish that recovered from ethanol exposure for the same amount of time (Fig. 1b, c). $\mathrm{Na}^{+}$and $\mathrm{K}^{+}$ levels did not differ between groups or exposure times (Fig. 2a, b). The lowest $\mathrm{Ca}^{2+}$ levels in the control group were observed after 10 min recovery.
Additionally, lower $\mathrm{Ca}^{2+}$ levels were observed in animals anesthetized with $50 \mu \mathrm{L} \mathrm{L}^{-1} \mathrm{EO}$ after 10 min recovery compared to the ethanol group at the same time (Fig. 2c).

\section{DISCUSSION}

The main constituents found in the EO obtained from leaves of $A$. polystachya were the monoterpenes carvone $(58.76 \%)$ and $\alpha$-limonene $(33.68 \%)$. Other studies also demonstrated the presence of carvone (González et al. 2010) and limonene in 
TABLE II

Time (in seconds) required for induction and recovery from anesthesia using the essential oil of Aloysia polystachya leaves (EO) in Epinephelus marginatus.

\begin{tabular}{|c|c|c|c|}
\hline $\begin{array}{c}\text { EO concentration } \\
\qquad\left(\mu \mathrm{L} \mathbf{L}^{-1}\right)\end{array}$ & Sedation & Anesthesia & Recovery \\
\hline 50 & $429.3 \pm 12.2$ & - & - \\
\hline 75 & $285.8 \pm 15.3$ & - & - \\
\hline 100 & $210.0 \pm 3.5$ & $1555.7 \pm 46.7$ & $565.0 \pm 9.3^{\mathrm{a}}$ \\
\hline 200 & $96.3 \pm 3.4$ & $313.4 \pm 16.8$ & $421.4 \pm 17.3^{b}$ \\
\hline 300 & $50.7 \pm 0.7$ & $163.7 \pm 16.5$ & $480.8 \pm 8.7^{\mathrm{b}}$ \\
\hline 400 & $46.5 \pm 1.6$ & $90.2 \pm 3.2$ & $330.5 \pm 13.0^{c}$ \\
\hline Equations & $\begin{array}{c}\mathrm{y}=684.4 \mathrm{e}^{(-0.01 \mathrm{x})} \\
\mathrm{r}^{2}=0.9529\end{array}$ & $\begin{array}{c}\mathrm{y}=6424.5 \mathrm{e}^{(-0.01 \mathrm{x})} \\
\mathrm{r}^{2}=0.9759\end{array}$ & - \\
\hline
\end{tabular}

Values are represented as mean \pm SEM $(n=6)$. Different letters indicate significant differences between essential oil concentrations in the recovery stage $(\mathrm{P}<0.05)$. Stages of anesthesia induction are according to Small $(2003)$, where sedation corresponds to Stage 1 and anesthesia corresponds to Stage 3. The equations fitted above represent a relationship between the times of anesthesia and concentrations of $\mathrm{EO}$, where $\mathrm{y}=$ time to reach the stage and $\mathrm{x}=$ concentration of $\mathrm{EO}$ of $A$. polystachya $\left(\right.$ in $\left.\mu \mathrm{L} \mathrm{L}^{-1}\right)$.

TABLE III

Blood parameters of Epinephelus marginatus evaluated after exposure (3.5 min) and recovery times from anesthesia induction by essential oil of Aloysia polystachya.

\begin{tabular}{|c|c|c|c|c|}
\hline & pH & $\mathrm{PvO}_{2}(\mathrm{~mm} \mathrm{Hg})$ & $\begin{array}{c}\mathrm{PvCO}_{2} \\
(\mathrm{~mm} \mathrm{Hg})\end{array}$ & $\begin{array}{c}\mathrm{HCO}_{3}^{-} \\
\left(\mathrm{mmoL} \mathrm{L}^{-1}\right)\end{array}$ \\
\hline \multicolumn{5}{|l|}{ Control } \\
\hline Exposure & $7.40 \pm 0.06^{\mathrm{a}}$ & $20.03 \pm 0.95^{\mathrm{a}}$ & $14.25 \pm 0.80^{\mathrm{a}}$ & $9.89 \pm 0.54^{\mathrm{a}}$ \\
\hline Recovery 5 min & $7.37 \pm 0.04^{\mathrm{a}}$ & $37.66 \pm 3.40^{\mathrm{b}}$ & $8.79 \pm 0.81^{\mathrm{b}}$ & $5.98 \pm 0.32^{\mathrm{b}}$ \\
\hline Recovery $10 \mathrm{~min}$ & $7.39 \pm 0.07^{\mathrm{a}}$ & $35.05 \pm 3.63^{\mathrm{b}}$ & $8.79 \pm 0.90^{b}$ & $5.98 \pm 0.42^{\mathrm{b}}$ \\
\hline \multicolumn{5}{|l|}{ Ethanol } \\
\hline Exposure & $7.32 \pm 0.08^{a}$ & $25.74 \pm 4.34^{\mathrm{a}}$ & $15.12 \pm 1.93^{\mathrm{a}}$ & $8.38 \pm 0.60^{\mathrm{a}}$ \\
\hline Recovery 5 min & $7.42 \pm 0.06^{\mathrm{a}}$ & $40.81 \pm 3.68^{b}$ & $8.29 \pm 0.72^{\mathrm{b}}$ & $5.36 \pm 0.24^{\mathrm{c}}$ \\
\hline Recovery $10 \mathrm{~min}$ & $7.38 \pm 0.03^{\mathrm{a}}$ & $25.05 \pm 4.28^{\mathrm{a}}$ & $11.24 \pm 0.78^{\mathrm{a}}$ & $6.55 \pm 0.07^{b}$ \\
\hline \multicolumn{5}{|l|}{ EO $50 \mu \mathrm{L} \mathrm{L}^{-1}$} \\
\hline Exposure & $7.49 \pm 0.03^{\mathrm{a}}$ & $60.97 \pm 3.39^{\mathrm{a} * \#}$ & $11.89 \pm 0.83^{\mathrm{a}}$ & $9.18 \pm 0.66^{\mathrm{a}}$ \\
\hline Recovery 5 min & $7.46 \pm 0.05^{\mathrm{a}}$ & $42.79 \pm 5.90^{b}$ & $8.74 \pm 1.05^{\mathrm{a}}$ & $5.25 \pm 0.43^{\mathrm{b}}$ \\
\hline Recovery $10 \mathrm{~min}$ & $7.40 \pm 0.05^{\mathrm{a}}$ & $36.08 \pm 3.70^{\mathrm{b}}$ & $9.20 \pm 0.68^{\mathrm{a}}$ & $5.72 \pm 0.32^{b}$ \\
\hline \multicolumn{5}{|l|}{ EO $300 \mu L L^{-1}$} \\
\hline Exposure & $7.28 \pm 0.06^{\mathrm{a}}$ & $37.48 \pm 3.16^{\mathrm{a} *}$ & $19.53 \pm 0.78^{\mathrm{a} *}$ & $8.93 \pm 0.81^{\mathrm{a}}$ \\
\hline Recovery 5 min & $7.19 \pm 0.05^{\mathrm{a}}$ & $61.20 \pm 4.69^{\mathrm{b} * \#}$ & $11.85 \pm 0.93^{\mathrm{b} * \#}$ & $4.65 \pm 0.46^{\mathrm{c}}$ \\
\hline Recovery $10 \mathrm{~min}$ & $7.46 \pm 0.07^{\mathrm{a}}$ & $44.24 \pm 0.95^{\mathrm{c* \#}}$ & $8.30 \pm 0.3^{6 \mathrm{c}} \#$ & $6.58 \pm 0.48^{b}$ \\
\hline
\end{tabular}

Values are represented as mean \pm SEM $(n=6)$. Different letters indicate significant difference within the same treatment $(\mathrm{P}<$ $0.05)$ * indicates significant difference from the control group at the same time and \# indicates significant difference from the ethanol group at the same time $(\mathrm{P}<0.05)$. 

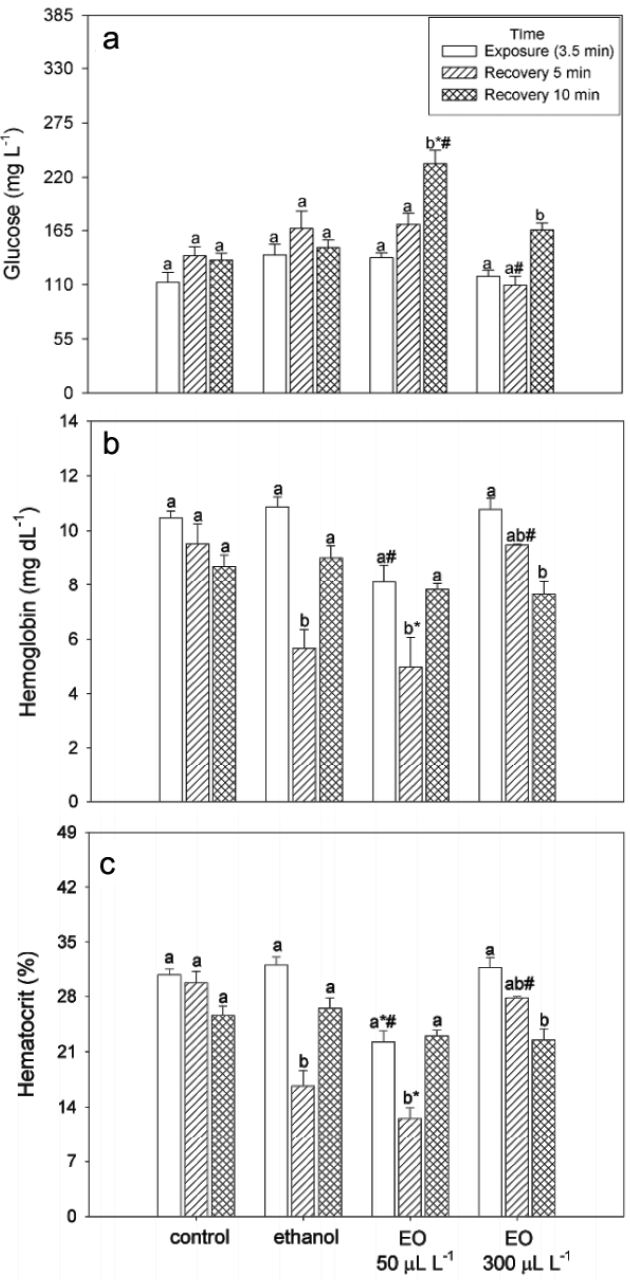

Figure 1 - Glucose (a), hemoglobin (b) and hematocrit (c) levels in Epinephelus marginatus after exposure to essential oil $(\mathrm{EO})$ of Aloysia polystachya added to the water $(\mathrm{n}=6)$. Values are represented as mean \pm SEM. Different letters indicate significant differences between times in the same treatment $(\mathrm{P}<0.05) .{ }^{*}$ indicates significant difference from the control group at the same time and \# indicates significant difference from the ethanol group at the same time $(\mathrm{P}<0.05)$.
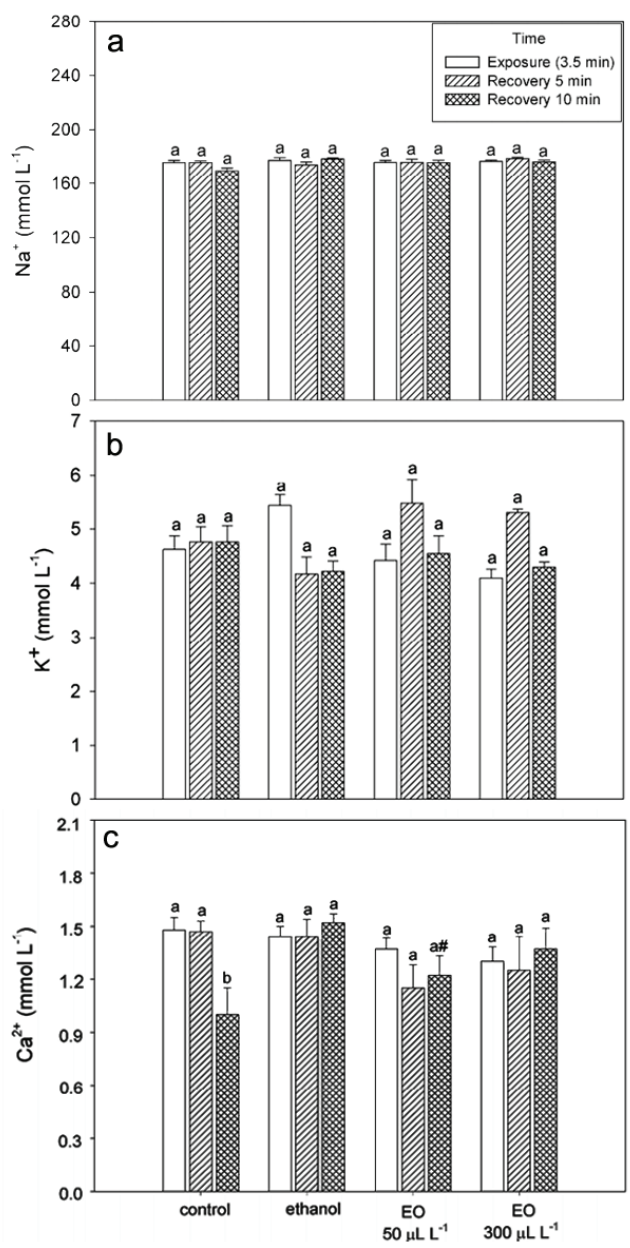

Figure 2 - Plasma $\mathrm{Na}^{+}(\mathbf{a}), \mathrm{K}^{+}$(b) and $\mathrm{Ca}^{2+}$ (c) levels in Epinephelus marginatus after exposure to essential oil (EO) of Aloysia polystachya added to the water ( $\mathrm{n}=6$ animals per group). Values are represented as mean \pm SEM. Different letters indicate significant differences between times in the same treatment $(\mathrm{P}<0.05) . *$ indicates significant difference from the control group at the same time and \# indicates significant difference from the ethanol group at the same time $(\mathrm{P}<0.05)$. 
this EO (Cabanillas et al. 2003). High contents of $\alpha$-thujone and $\beta$-thujone (which were not found in the present study) were previously detected in this EO (Cabanillas et al. 2003, Duschatzky et al. 2004).

The present study demonstrated that $A$. polystachya EO has an anesthetic effect on grouper juveniles. This EO induced sedation at all concentrations tested and anesthetized animals within 3 and $1.5 \mathrm{~min}$ (300 and 400 $\mu \mathrm{L} \mathrm{L}^{-1}$, respectively). Recovery time for both concentrations was about $8 \mathrm{~min}$ and $5 \mathrm{~min}$, respectively, and no mortality was observed as a result of anesthesia induction. These findings are in accordance with literature criteria (Marking and Meyer 1985, Gilderhus and Marking 1987, Keene et al. 1998, Park et al. 2009). Parodi et al. (2014) tested the anesthetic effect of the EO obtained from another species of Aloysia, namely A. triphylla, in concentrations ranging between 20 and $800 \mu \mathrm{L} \mathrm{L}^{-1}$ on two strains (albino and gray) of silver catfish (Rhamdia quelen), and $200 \mu \mathrm{L} \mathrm{L}^{-1} \mathrm{EO}$ was the best concentration to induce anesthesia in the albino strain, while for the gray strain it was $400 \mu \mathrm{L} \mathrm{L}^{-1}$ EO. An emulsified mixture composed of Mentha spicata EO and methyl salicylate oil (containing $28.4 \%$ L-carvone) anesthetized common carp (Cyprinus carpio) within the recommended time at $395 \mu \mathrm{L} \mathrm{L}^{-1}$ (Roohi and Imanpoor 2014) and Atlantic salmon (Salmo salar) at $257 \mu \mathrm{L} \mathrm{L}^{-1}$ (Danner et al. 2011), but M. spicata $\mathrm{EO}$ alone induced anesthesia in less than 3 min only at $5000 \mu \mathrm{L} \mathrm{L}^{-1}$ (Roohi and Imanpoor 2015). Interestingly, increased EO concentration promoted recovery time decrease. Other EOs produced higher recovery times as the EO concentration increased (Cunha et al. 2010, Heldwein et al. 2012, Silva et al. 2012, 2013, Parodi et al. 2014). Since EOs are complex mixtures of compounds, a particular biological activity such as induction and recovery times from anesthesia depends on the specific chemical characteristics of each EO, including the qualitative composition and the proportions of each component in the oil (Raut and Karuppayil 2014).

The sedative and anesthetic activity of the EO of $A$. polystachya can be explained mainly by the combined action of its major components, the monoterpenoid-derived compounds carvone and limonene, which account for $92.44 \%$ of its total chemical composition. Carvone has a central nervous system (CNS) depressant effect detected in different pre-clinical studies in mice (Sousa et al. 2007), while limonene acts as an agonist for adenosine A2A receptors, and consequently can induce sedative effects (Park et al. 2011). Limonene also inhibited stimulant-induced behavioral changes in mice and rats, by regulating dopamine levels and 5-HT receptor function (Yun 2014). However, it is likely that a contribution to the activity detected in groupers is made by the minor components, such as limonene epoxide, for which an anxiolytic-like effect was detected in mice. The CNS effects of this compound were reversed by flumazenil, indicating a GABAergic mechanism of action (Almeida et al. 2012).

The blood $\mathrm{pH}$ values of the groupers, regardless of exposure time or group, were similar to or slightly lower than those reported for red pacu (Piaractus brachypomus) exposed to MS-222 and eugenol at 50, 100 and $200 \mathrm{mg} \mathrm{L}^{-1}$ (Sladky et al. 2001), yellow perch (Perca flavescens), walleye pike (Sander vitreus) and common carp anesthetized with buffered MS-222 (150 mg L ${ }^{-1}$ ) (Hanley et al. 2010); silver catfish transported for $4 \mathrm{~h}$ in plastic bags with eugenol $\left(1.5\right.$ or $\left.3.0 \mu \mathrm{L} \mathrm{L}^{-1}\right)$ and $L$. alba EO (10 or $\left.20 \mu \mathrm{L} \mathrm{L}^{-1}\right)$ added to the water (Becker et al. 2012). The $\mathrm{pH}$ values observed in the blood of groupers were not affected by $A$. polystachya EO exposure, in accordance with the lack of effect of eugenol and L. alba $\mathrm{EO}$ on this parameter in silver catfish (Becker et al. 2012).

The $\mathrm{PvO}_{2}, \mathrm{PvCO}_{2}$ and $\mathrm{HCO}_{3}^{-}$values were within the range reported by other studies (Sladky et al. 2001, Souza et al. 2001, Hanley et al. 2010, 
Becker et al. 2012). The handling (simulated recovery) of control groupers increased $\mathrm{PvO}_{2}$ and decreased $\mathrm{PvCO}_{2}$ and $\mathrm{HCO}_{3}{ }^{-}$values, probably due to hyperventilation. Exposure to $50 \mu \mathrm{L} \mathrm{L}^{-1}$ A. polystachya $\mathrm{EO}$ (and $300 \mu \mathrm{L} \mathrm{L}^{-1}$ compared to control fish) increased $\mathrm{PvO}_{2}$, as was also observed by Hanley et al. (2010) in perch, walleye and common carp anesthetized with MS-222. $\mathrm{PvCO}_{2}$ only increased in groupers exposed to $50 \mu \mathrm{L} \mathrm{L}^{-1}$ A. polystachya EO, as observed by Sladky et al. (2001) in red pacu exposed to MS-222 and eugenol. However, as in groupers exposed to $50 \mu \mathrm{L} \mathrm{L}^{-1} A$. polystachya EO, Hanley et al. (2010) reported that $P v \mathrm{CO}_{2}$ did not change in perch, walleye or common carp anesthetized with MS-222.

In the present study, the handling of simulated exposure did not induce a significant increase in blood glucose levels, but groupers anesthetized with $50 \mu \mathrm{L} \mathrm{L}^{-1} A$. polystachya EO after $10 \mathrm{~min}$ recovery showed increased levels compared to those after exposure. Repetitive blood sampling increased blood glucose levels in rainbow trout (Oncorhynchus mykiss) and anesthesia with clove oil or MS-222 did not change this pattern (Wagner et al. 2003).

Hematocrit values found in this study (26$31 \%$ ) in fish exposed to control conditions were similar to those reported by Becker et al. (2012) (26-33\%) and Carneiro et al. (2009) (27-30\%) in silver catfish. The lower hematocrit and hemoglobin values in recovered ethanol and $50 \mu \mathrm{L} \mathrm{L}^{-1}$ EO (5 min) and $300 \mu \mathrm{L} \mathrm{L}^{-1} \mathrm{EO}$ (10 min) groups compared to exposed fish indicate possible hemodilution or decreased red cell number. Contrary to our results, anesthesia with clove oil or MS-222 reduced hematocrit decrease produced by repetitive sampling in rainbow trout (Wagner et al. 2003).

Ionoregulatory homeostasis is important to ensure proper cell function (Hwang et al. 2011). Moreover, stress due to usual aquaculture procedures is known to affect fish ionoregulation (Ashley et al. 2007). Addition of some sedatives to water can reduce ion loss in fish (Becker et al. 2012). Ionoregulation in groupers was not affected by anesthesia with $A$. polystachya EO, because the only change was lower $\mathrm{Ca}^{2+}$ in fish after $10 \mathrm{~min}$ recovery from $50 \mu \mathrm{L} \mathrm{L}^{-1} \mathrm{EO}$ exposure compared to those recovered from ethanol exposure. Anesthesia with $H$. ringens and L. alba EOs (150, 300 or 450 $\mu \mathrm{L} \mathrm{L}^{-1}$ ) and recovery did not considerably affect plasma $\mathrm{Na}^{+}$and $\mathrm{Cl}^{-}$levels either (Toni et al. 2014). Blood $\mathrm{Na}^{+}$also did not change, but $\mathrm{K}^{+}$increased in red pacu anesthetized with MS-222 and eugenol (Sladky et al. 2001).

\section{CONCLUSIONS}

The EO from the leaves of $A$. polystachya was an effective sedative and anesthetic for dusky grouper juveniles in concentrations similar to those found for other EOs in other species. Some of the tested blood parameters showed compensatory responses due to EO exposure, but most changes returned to control values after $10 \mathrm{~min}$ of recovery.

\section{ACKNOWLEDGMENTS}

This study was supported by Fundação de Amparo à Pesquisa do Estado do Rio Grande do Sul/Programa de Apoio a Núcleos de Excelência (FAPERGS/ PRONEX, process 10/0016-8), Conselho Nacional de Desenvolvimento Científico e Tecnológico (CNPq, process 470964/2009-0) and Coordenação de Aperfeiçoamento de Pessoal de Nível Superior, Brazil (CAPES) for research fellowships and financial support.

\section{REFERENCES}

ADAMS RP. 2009. Identification of essential oil components by gas chromatography/mass spectrometry, $4^{\text {th }}$ ed., Illinois: Allured Publishing Corporation, 804 p.

ALMEIDA AAC, COSTA JP, CARVALHO RBF, SOUSA DP AND FREITAS RM. 2012. Evaluation of acute toxicity of a natural compound (+)-limonene epoxide and its anxiolytic-like action. Brain Res 1448: 56-62. 
ASHLEY PJ. 2007. Fish welfare: current issues in aquaculture. App Anim Behav Sci 104: 199-235.

AZAMBUJA CR, MATTIAZZI J, RIFFEL APK, FINAMOR IA, GARCIA LO, HELDWEIN CG, HEINZMANN BM, BALDISSEROTTO B, PAVANATO MA AND LLESUY SF. 2011. Effect of the essential oil of Lippia alba on oxidative stress parameters in silver catfish (Rhamdia quelen) subjected to transport. Aquaculture 319: 156-161.

BAUMGARTEN MGZ, ROCHA JMB AND NIENCHESKY LF. 1996. Manual de análises em oceanografia química, Rio Grande: FURG, 172 p.

BECKER AG, PARODI TV, HELDWEIN CG, ZEPPENFELD CC, HEINZMANN BM AND BALDISSEROTTO B. 2012. Transportation of silver catfish, Rhamdia quelen, in water with eugenol and the essential oil of Lippia alba. Fish Physiol Biochem 38: 789-796.

BENDSCHNEIDER K AND ROBINSON RJ. 1952. A new spectrophometric method for the determination of nitrite in sea water. J Mar Res 11: 87-96.

CABANILLAS CM, LOPEZ ML, DANIELE G AND ZYGADLO JA. 2003. Essential oil composition of Aloysia polystachya (Griseb) Moldenke under rust disease. Flavour Frag J 18: 446-448.

CARNEIRO PCF, KAISELER PHS, SWAROFSKY EAC AND BALDISSEROTTO B. 2009. Transport of jundiá Rhamdia quelen juveniles at different loading densities: water quality and blood parameters. Neotrop Ichthyol 7: 283-288.

CAVALLI RO. 2014. Maricultura. In: Castello JP. Introdução às ciências do mar, Pelotas: Editora Textos, p. 418-455.

COOKE SJ ET AL. 2008. Effects of different capture techniques on the physiological condition of bonefish Albula vulpes evaluated using field diagnostic tools. J Fish Biol 73: 1351-1375.

CUNHA MA, BARROS FMC, GARCIA LO, VEECK APL, HEINZMANN BM, LORO VL, EMANUELLI T AND BALDISSEROTTO B. 2010. Essential oil of Lippia alba: a new anesthetic for silver catfish, Rhamdia quelen. Aquaculture 306: 403-406.

CUNHA ME, RÉ P, QUENTAL-FERREIRA H, GAVAIA PJ AND POUSÃO-FERREIRA P. 2013. Larval and juvenile development of dusky grouper Epinephelus marginatus reared in mesocosms. J Fish Biol 83: 448-465.

DANNER GR, MUTO KW, ZIEBA AM, STILLMAN CM, SEGGIO JA AND AHMAD ST. 2011. Spearmint (1-carvone) oil and wintergreen (methyl salicylate) oil emulsion is an effective immersion anesthetic of fishes. $\mathrm{J}$ Fish Wildl Manage 2: 146-155.

DEL VITTO LA AND PETENATTI EM. 1997. Recursos herbolarios de San Luis (República Argentina) Primeira parte: plantas nativas. Multequina 6: 49-66.

DUSCHATZKY CB, MARTINEZ AN, ALMEIDA NV AND BONIVARDO SL. 2004. Nematicidal activity of the essential oils of several Argentina plants against the rootknot nematode. J Essent Oil Res 16: 626-628.

EUROPEAN PHARMACOPOEIA. 2007. European directorate for the quality of medicines, $6^{\text {th }}$ ed., Strassbourg.

FENNESSY YST. 2006. Reproductive biology and growth of the yellowbelly rockcod Epinephelus marginatus (Serranidae) from South-East Africa. Afr J Mar Sci 28: 1-11.

FILIPOY A. 1994. Medicinal plants of the Pilaga of Central Chaco. J Ethnopharmacol 44: 181-193.

FIGUEIREDO JL AND MENEZES NA. 1980. Manual de peixes marinhos do sudeste do Brasil III Teleostei (2) São Paulo, Museu de Zoologia, Universidade de São Paulo, $90 \mathrm{p}$.

GILDERHUS PA AND MARKING LL. 1987. Comparative efficacy of 16 anesthetic chemicals on rainbow trout. N Am J Fish Manage 7: 288-292.

GONZÁLEZ JOW, GUTIERREZ MM, MURRAY AP AND FERRERO AA. 2010. Biological activity of essential oils from Aloysia polystachya and Aloysia citriodora (Verbenaceae) against the soybean pest Nezara viridula (Hemiptera: Pentatomidae). Nat Prod Commun 5: 301306.

GRESSLER LT ET AL. 2014. Silver catfish Rhamdia quelen immersion anesthesia with essential oil of Aloysia triphylla (L'Hérit) Britton or tricaine methanesulfonate: effect on stress response and antioxidant status. Aquac Res 45: 1061-1072.

HANLEY CS, CLYDE VL, WALLACE RS, PAUL-MURPHY J, PATTERSON TA, KEULER NS AND SLADKY KK. 2010. Effects of anesthesia and surgery on serial blood gas values and lactate concentrations in yellow perch (Perca flavescens), walleye pike (Sander vitreus), and koi (Cyprinus carpio). JAVMA - J Am Vet Med A 236: 11041108.

HELDWEIN CG, SILVA LL, RECKZIEGEL P, BARROS FM, BALDISSEROTTO B, MALLMANN CA, SCHMIDT D, CARON BO AND HEINZMANN BM. 2012. Participation of the GABAergic system in the anesthetic effect of Lippia alba (Mill) N E Brown essential oil. Braz J Med Biol Res 45: 436-443.

HELLIÓN-IBARROLA MC ET AL. 2008. The antidepressantlike effects of Aloysia polystachya (Griseb) Moldenke (Verbenaceae) in mice Phytomedicine, 15: 478-483

HELLIÓN-IBARROLA MC ET AL. 2006. The anxiolyticlike effects of Aloysia polystachya (Griseb) Moldenke (Verbenaceae) in mice. J Ethnopharmacol 105: 400-408.

HWANG PP, LEE TH AND LIN LY. 2011. Ion regulation in fish gills: recent progress in the cellular and molecular mechanisms. Am J Physiol-Reg I 301: R28-R47.

IRIGOYEN AJ, GALVAN DE AND VENERUS LA. 2005. Occurrence of dusky grouper Epinephelus marginatus 
(Lowe, 1834) in gulfs of northern Patagonia, Argentina. J Fish Biol 67: 1741-1745.

KEENE JL, NOAKES DLG, MOCCIA RD AND SOTO CG. 1998. The efficacy of clove oil as an anaesthetic for rainbow trout, Oncorhynchus mykiss (Walbaum). Aquac Res 29: 89-101.

KIESSLING A, JOHANSSON D, ZAH LIH AND SAMUELSEN OB. 2009. Pharmacokinetics, plasma cortisol and effectiveness of benzocaine, MS-222 and isoeugenol measured in individual dorsal aortacannulated Atlantic salmon (Salmo salar) following bath administration. Aquaculture 86: 301-308.

KRISTENSEN T, ROSSELAND BO KIESSLING A, DJORDEVIC B AND MASSABAU JC. 2010. Lack of arterial PO2 downregulation in Atlantic salmon (Salmo salar L.) during long-term normoxia and hyperoxia. Fish Physiol Biochem 36: 1087-1095.

MARKING LL AND MEYER FP. 1985. Are better fish anesthetics needed in fisheries? Fisheries 10: 2-5.

MORA S, DÍAZ-VÉLIZ G, MILLÁN R, LUNGENSTRASS H, QUIRÓS S, COTO-MORALES T AND HELLIÓNIBARROLA MC. 2005. Anxiolytic and antidepressantlike effects of the hydroalcoholic extract from Aloysia polystachya in rats. Pharmacol Biochem Behav 82: 373378.

NIST. 2008. Databank NIST/EPA/NIH mass spectral library and search/analysis programs Hoboken: J Wiley \& Sons.

PARK HM, LEE JH, YAOYAO J, JUN HJ AND LEE SJ. 2011. Limonene, a natural cyclic terpene, is an agonistic ligand for adenosine $\mathrm{A}_{2 \mathrm{~A}}$ receptors. Biochem Biophys Res Commun 404: 345-348.

PARK IS, PARK MO, HUR JW, KIM DS, CHANG YJ, KIM YJ, PARK JY AND JOHNSON SC. 2009. Anesthetic effects of lidocaine-hydrochloride on water parameters in simulated transport experiment of juvenile winter flounder, Pleuronectes americanus. Aquaculture 294: 76-79.

PARODI TV, CUNHA MA, BECKER AG, ZEPPENFELD CC, MARTINS DI, KOAKOSKI G, BARCELLOS LJG, HEINZMANN BM AND BALDISSEROTTO B. 2014. Anesthetic activity of the essential oil of Aloysia triphylla and effectiveness in reducing stress during transport of albino and gray strains of silver catfish, Rhamdia quelen. Fish Physiol Biochem 40: 323-334.

PAUST LO, FOSS A AND IMSLAND AK. 2011. Effects of chronic and periodic exposure to ammonia on growth, food conversion efficiency and blood physiology in juvenile Atlantic halibut (Hippoglossus hippoglossus L.). Aquaculture 315: 400-406.

RAUT JS AND KARUPPAYIL SM. 2014. A status review on the medicinal properties of essential oils. Ind Crop Prod 62: 250-264.

ROOHI Z AND IMANPOOR MR. 2014. Effects of spearmint (/-carvon) oil and methyl salicylate oil emulsion on anesthesia of common carp (Cyprinus carpio L., 1758). Aquac Res Dev 5: 1-5.

ROOHI Z AND IMANPOOR MR. 2015. The efficacy of the oils of spearmint and methyl salicylate as new anesthetics and their effect on glucose levels in common carp (Cyprinus carpio L., 1758) juveniles. Aquaculture 437: 327-332.

SALBEGO J ET AL. 2014. The essential oil from Lippia alba induces biochemical stress in the silver catfish (Rhamdia quelen) after transportation. Neotrop Ichthyol 12: 811-818.

SANCHES ES, SILVA FC, LEITE JR, SILVA PKA, KERBER CE AND SANTOS PA. 2014. A incorporação de óleo de peixe na dieta pode melhorar o desempenho da garoupaverdadeira Epinephelus marginatus? Bol Inst Pesca 40: 147-155.

SILVA LL, PARODI TV, RECKZIEGEL P, GARCIA VO, BURGER ME, BALDISSEROTTO B, MALLMANN CA, PEREIRA AMS AND HEINZMANN BM. 2012. Essential oil of Ocimum gratissimum L. anesthetic effects, mechanism of action and tolerance in silver catfish, Rhamdia quelen. Aquaculture 350: 91-97.

SILVA LL, SILVA DT, GARLET QI, CUNHA MA, MALLMANN CA, BALDISSEROTTO B, LONGHI SJ, PEREIRA AMS AND HEINZMANN BM. 2013. Anesthetic activity of Brazilian native plants in silver catfish (Rhamdia quelen). Neotrop Ichthyol 11: 443-451.

SLADKY KK, SWANSON CR, STOSKOPF MK, LOOMIS MR AND LEWBART GA. 2001. Comparative efficacy of tricaine methanesulfonate and clove oil for use as anesthetics in red pacu (Piaractus brachypomus). Am J Vet Res 62: 337-342.

SMALL BC. 2003. Anesthetic efficacy of metomidate and comparison of plasma cortisol responses to tricaine methanesulfonate, quinaldine and clove oil anesthetized channel catfish Ictalurus punctatus. Aquaculture 218: 177 185.

SOUSA DP, NÓBREGA FFF AND ALMEIDA RN. 2007. Influence of the chirality of $(R)-(-)$ - and (S)-(+)-carvone in the central nervous system: a comparative study. Chirality 19: 264-268.

SOUZA RHD, SONCINI R, GLASS ML, SANCHES JR AND RANTIN FT. 2001. Ventilation, gill perfusion and blood gases in dourado, Salminus maxillosus Valenciennes (Teleostei, Characidae), exposed to graded hypoxia. J Comp Physiol B 171: 483-489.

TONI C, BECKER AG, SIMÕES LN, PINHEIRO CG, SILVA LL, HEINZMANN BM, CARON BO AND BALDISSEROTTO B. 2014. Fish anesthesia: effects of the essential oils of Hesperozygis ringens and Lippia alba on the biochemistry and physiology of silver catfish (Rhamdia quelen). Fish Physiol Biochem 40: 701-714. 
UNESCO. 1983. Chemical methods for use in marine environmental monitoring. Manual and guides 12, Paris: Intergovernamental Oceanographic Commission.

WAGNER GN, SINGER TD AND MCKINLEY RS. 2003. The ability of clove oil and MS-222 to minimize handling stress in rainbow trout (Oncorhynchus mykiss W). Aquac Res 34: 1139-1146.

YUN J. 2014. Limonene inhibits methamphetamine-induced locomotor activity via regulation of 5-HT neuronal function and dopamine release. Phytomedicine 21: 883887.

ZAHL IH, SAMUELSEN O AND KIESSLING A. 2012. Anaesthesia of farmed fish: implications for welfare. Fish Physiol Biochem 38: 201-218.

ZEPPENFELD CC ET AL. 2014. Physiological and biochemical responses of silver catfish, Rhamdia quelen, after transport in water with essential oil of Aloysia triphylla (L'Herit) Britton. Aquaculture 418-419: 101-107. 